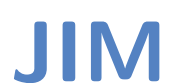

ISSN: 2183-0606

(CC BY 3.0)

Vol. 9, $1(2021)$

p. $25-50$

AM: Feb2021

SM: Set2020

\title{
The Role of Dynamic Capabilities in Firm-Level Technology Adoption Processes: A Qualitative Investigation
}

\author{
Kenneth W. Graham ${ }^{1}$ and Robert S. Moore ${ }^{2}$ \\ ${ }^{1}$ University of Wisconsin-La Crosse -1725 State Street, La Crosse, WI 54601 United States | \\ kgraham2@uwlax.edu \\ ${ }^{2}$ Mississippi State University | rmoore@business.msstate.edu
}

\begin{abstract}
Increasingly, marketers rely on advances in technology to maintain competitive parity or to gain competitive advantage. Yet often the adoption of technology is met with suboptimal results and even outright failure. Qualitative field research based on depth interviews with business managers responsible for technology adoption decisions within their respective firms is used to develop a theoretical framework explaining the technology adoption process within firms, how expectations are formed for the innovation's performance and factors that can further influence those perceptions. Results suggest a firm's dynamic capabilities play a central role in informing the firm's perceptions of a technological innovation's characteristics that drive the adoption decision. Findings also suggest that a firm's expectations are influenced by its perception of risk, internal micro-political actions, and the opportunity to observe or trial use of the technological innovation.
\end{abstract}

Keywords: Technology Adoption; Dynamic Capabilities; Micro-politics; Absorptive Capacity, Diffusion of Innovations; Sense and Response Capabilities; Technological Opportunism; Qualitative.

Cite paper as: Graham, K.W., Moore, R.S., (2021). The Role of Dynamic Capabilities in Firm-Level Technology Adoption Processes: A Qualitative Investigation, Journal of Innovation Management, 9(1), 25-50.; DOI: https://doi.org/10.24840/2183-0606_009.001_0004

\section{Introduction}

In industrial markets, a key way firms create value and improve financial performance is by leveraging strategic resources, innovation capabilities, and business-to-business partnerships to develop new products and processes that enhance strategic advantage (Park \& Lee, 2015; Mai Anh, Hui, \& Khoa, 2018). Innovation capability is defined as the ability to develop new technologies or to significantly improve or modify existing technology (Wonglimpiyarat, 2010). However, many firms lack the capabilities or resources to innovate internally; therefore, they must adopt value-adding technological innovations from sources external to the firm to achieve their performance objectives. To identity efficiencies and opportunities to better meet the needs of customers and supply chain partners, manufacturers are increasingly adopting technological innovations such as precision 3D rapid prototyping technology, automated service technology, artificial intelligence, and advanced analytical software to manage and mine big data (Hughes, 2017).

Unfortunately, not all firm-level technology adoption decisions are successful, which places firm performance, and supplier and customer relationships at risk. Research suggests that buying center complexity, misalignment of organizational goals, and conflicting norms across functional areas of the firm can negatively impact the outcomes of technology adoption decisions (Bunduchi, et al., 
2015). For example, in 2013 16,000 of Avon's Canadian salesforce quit the firm in opposition to its recently adopted order management system. This forced Avon to abandon a $\$ 125$ million investment in the technology (Henschen, 2013; Fitzgerald, 2013). Similarly, in 2010, Lumber Liquidators Holdings, Inc. invested heavily in an enterprise resource planning system designed to increase efficiency and customer convenience. However, poor implementation of the technology resulted in severely reduced productivity and cost the firm between $\$ 12$ and $\$ 14$ million in lost sales (Krigsman, 2010; Kanaracus, 2010).

While a substantial body of research exists that examines the firm's innovation capabilities and its ability to innovate internally (see Slater, Mohr, \& Sengupta, 2014; Yaghoubi et al., 2017), surprisingly few studies exist that examine firm capabilities that influence its ability to successfully adopt innovations. Much of the research that explores firm-level technology adoption decisions examine drivers of the adoption decision based on the attributes of the technology as identified by Rogers (1962), (relative advantage, perceived compatibility, perceived complexity, observability and trialability; see also Kapoor, Dwivedi, \& Williams, 2014). The literature also examines characteristics of the adopting firm as drivers of the adoption decision, including firm size, organizational structure, and organizational innovativeness (e.g. Frambach and Schillwaert, 2002; Jelinek, et al., 2006). While the extant literature provides substantial findings in support of adoption decision drivers, it fails to effectively identify those aspects of the technology adoption decision process that lead to suboptimal outcomes of the adoption decision. Obal (2017, p. 42) suggests firms adopting disruptive technology should "aim to increase their searching efforts in order to better understand technology prior to adoption." Abrahamson (1991) argues that innovation research focuses too much on what drives adoption decisions and too little on what drives firms to adopt inferior innovations or to reject superior ones.

Therefore, to address the gap Abrahamson (1991) observed regarding technological innovation adoption and to explore the role a firm's dynamic capabilities play in affecting the outcome of technology adoption decisions, this research using qualitative methods seeks to address the following research questions:

- RQ1: What role do the dynamic capabilities of a firm play in the evaluation and adoption of technological innovations?

- RQ2: What factors influence a firm's perceptions of technological innovations?

The remainder of this paper is organized as follows: first, a review of the technological innovation adoption and relevant dynamic capabilities literature is presented. The review of the literature is followed by a discussion of research methods, including the design, execution and analysis of an exploratory qualitative study using semi-structured depth interviews with key informants to address the research questions. The methods section is followed by a discussion of the research findings, their implications for theory and practice, and the development of research propositions based on the analysis.

\section{Literature Review}

Firm-level technology adoption decision processes occur in two stages - an initiation stage and a post-adoption implementation stage (Zaltman, Duncan, \& Holbeck, 1973). This process is frequently examined in the context of expectancy-disconfirmation theory (EDT; Oliver, 1980). EDT holds that during the initiation stage, adopters of an innovation form perceptions and attitudes about a technological innovation and expectations for its performance based on acquired knowledge and previous experience. In the implementation stage, satisfaction (or dissatisfaction) 
occurs depending on how well the firm's expectations for the innovation's performance matched the actual performance of the adopted technology. Unrealistically high performance expectations result in lower post-adoption performance evaluations versus when initial expectations are more realistic (Staples, et al., 2002).

\subsection{Firm-level Technological Innovation Adoption}

In the technology adoption literature, the most frequently studied performance expectations include perceptions of the innovation's relative advantage, compatibility, and complexity (Kapoor, et al., 2014; Rogers, 1962). Relative advantage refers to the degree to which an organization perceives an innovation to be better than the next best alternative (Rogers, 1995; Frambach \& Schillewaert, 2002). Rogers (1995) further defines perceived compatibility as the perception that an innovation is congruous with a firm's values, needs, and experiences. The complexity of an innovation is an assessment of the perceived difficulty associated with an innovation's acquisition, implementation and/or use (Rogers 1995; Nooteboom 1989). Perceptions of these attributes are shown in the literature to be directly associated with technology adoption decisions made at the firm level (Heide and Weiss, 1995; Frambach \& Schillewaert, 2002; O'Neal, Thorelli, \& Utterback, 1973).

In addition to perceptions of characteristics of a technology, the adoption decision is also influenced by the cultural and structural characteristics of the adopting entity (Rogers 1962; O'Neal, Thorelli, and Utterback, 1973; Davis, 1989). Firm innovativeness, size, centralization of decision-making and formalization of procedures are among the most commonly studied firm characteristics shown to influence technology adoption decisions. Firm innovativeness refers to the capacity of the firm to develop innovative products, processes or technologies (Deshpandé, Farley \& Webster, 1993). This capability is positively associated with firm financial performance (Hurley \& Hult, 1998), and market position (Rubera \& Kirca, 2012). Innovative firms are entrepreneurial in nature and are less risk averse (Moorman, 1995); thus, they are more willing to adopt innovations than risk-adverse firms. Further, firm innovativeness is positively associated with the size of a firm; thus, larger firms tend to be more innovative (Rogers, 1995). Additionally, structural characteristics of the firm, including centralization and formalization tend to be negatively related to firm innovativeness. The centralization of power and decision-making in the firm restricts the range of new ideas a firm is exposed to (Rogers, 1995; Damanpour, 1991); thus, firms with centralized decision making that rely on formalized procedures are often slower to adopt new technology than are firms with less centralized authority or formality of procedures.

Finally, to understand the process by which technological innovations are adopted by a firm, it is important to consider the political nature of the firm, the political strategies that are undertaken to gain approval for the innovation, and their influence on organizational decision-making. Micropolitics are political actions at the organizational level and are defined as "intentional acts of influence undertaken by individuals or groups to enhance or protect their self-interest when conflicting courses of action are possible" (Gray \& Ariss, 1985). Prior micro-political research has focused on specific strategies that influence firm decision-making (Sethi, Iqbal, \& Sethi, 2012; Narayanan \& Fahey, 1982; Zahra 1987), employee satisfaction (Witt, Andrews \& Kacmar, 2000), and perceptions of innovativeness (Parker, Dipboye, \& Jackson, 1995). Micro-political constructs frequently observed include coalition building and framing (Lechner \& Floyd, 2012; Sethi, Iqbal \& Sethi, 2012; Durmusoglu, Hirunyawipada, \& McNally, 2017), both of which have been shown to influence strategic decisions regarding the adoption of technology (e.g. Sethi, lqbal, \& Sethi, 2012). 


\subsection{Dynamic Capabilities}

Broadly defined, dynamic capabilities are mechanisms by which firms achieve new configurations of resources in rapidly changing markets (Eisenhardt \& Martin 2000). Christensen (2011) argues that a firm's capabilities and accumulated knowledge influence expectations for the performance of an innovation, the allocation of resources, and the types of innovations the firm pursues. As an organization accumulates knowledge and experience, it develops knowledge-based resources that can be utilized to co-create value for its customers (Mustak, 2019). Research suggests that a firm's knowledge resources are a source of competitive advantage (Vargo \& Lusch, 2004), are positively related to the firm's level of innovativeness (Cohen \& Levinthal, 1990) and are positively related to its ability to exploit opportunities for commercial gain (Jansen, Van Den Bosch, \& Voberda, 2005). The competitive advantages received from existing knowledge-based resources may be short lived in dynamic markets, thus it is important that firms reconfigure, adapt or develop new resources to remain competitive (Teece, Pisano, \& Shuen 1997). Thus, the more developed a firm's knowledge-based dynamic capabilities, the better its capacity to evaluate knowledge related to an innovation and exploit that knowledge to enhance financial performance by adopting it.

\section{Absorptive Capacity}

Firms acquire knowledge about their environments in several ways. Absorptive capacity is a knowledge-based dynamic capability of the firm that can influence knowledge transfer and organizational learning (Choi, Jean, \& Kim, 2019), inform innovation adoption decisions and provide a source of competitive advantage resulting in superior financial performance (Del Carpio Gallegos \& Torner, 2018). Indeed, Lin et al. (2016) find that absorptive capacity has a direct relationship with the initiation, external information search, proposal establishment and implementation stages of the management innovation adoption process. Absorptive capacity is described as organizational processes by which firms acquire, assimilate, transform and exploit knowledge to produce a dynamic organizational capability (Zahra \& George, 2002). Knowledge acquisition refers to the ability to identify and obtain external information that is valuable to the firm (Zahra \& George, 2002). Knowledge assimilation is defined as the "routines and processes that allow [the firm] to analyze, process, interpret, and understand the information obtained" (Zahra \& George, 2002; p. 189). Thus, assimilation relies on the shared interpretation of the new knowledge and the integration of the new knowledge into the organizational memory (Flatten, et al., 2011). Tordova \& Durisin (2007) describe knowledge transformation as an alternative condition to knowledge assimilation. Assimilated knowledge easily incorporates into the firm's existing context and cognitive structures (Zahra \& George, 2002); however, knowledge transformation requires the adaptation of existing knowledge schemas to accommodate new knowledge that is inconsistent with current understanding (Tordova \& Durisin, 2007; Zahra \& George, 2002). Finally, knowledge exploitation is the firm's ability to alter existing routines, functional capabilities or technologies to create something new based on the newly integrated knowledge (del Carmen, et al., 2007). It is through the exploitation of knowledge that the firm garners competitive advantage from its absorptive capacity dynamic capability (Zobel, 2017).

\section{Technological Opportunism}

In rapidly changing environments, the ability to acquire knowledge resources and assess the need to adapt to those changes requires both the continual monitoring of markets and technologies as well as a willingness to make necessary adjustments to take advantage of opportunities (Teece, Pisano, \& Shuen 1997; Adams \& Graham, 2017). Lin et al. (2016) find the firm's sensing dynamic capability is positively associated with the initiation, outside search, and implementation stages of 
the management innovation adoption process. Similarly, they find the firm's integrative dynamic capability is positively associated with the initiation, proposal establishment, and implementation stages of the management innovation adoption process.

Srinivasan, Lilien, \& Rangaswamy (2002) identify technological opportunism as a dynamic capability that describes the firm's ability to sense and respond to new technologies it observes in its environment. Further, technological opportunism is identified as a key determinant of technology adoption decisions (Srinivasan, Lilien, \& Rangaswamy, 2002; Lucia-Palacios et al., 2014). Additionally, research suggests technological opportunism has a direct influence on firm financial performance (Sarkees, 2011; Chen \& Lien, 2013), non-financial performance measures, including perceptions of customer relationship quality and market differentiation (Lucia-Palacios et al., 2014), and on firm adoption decisions and integration capabilities (Mishra \& Agarwal 2010; Lucia-Palacios et al., 2014).

\section{Technological Opportunism vs. Absorptive Capacity}

Absorptive capacity has been shown to be a broad-based firm dynamic capability by which the learning organization captures, assimilates, internalizes and exploits new knowledge it perceives to be of value based on the firm's existing knowledge resources (Cohen \& Levinthal, 1990). Organizational learning that is driven by absorptive capacity is based on the assumption that the firm's internal and external environments are analyzable and that knowledge can be gained either passively, through routine data collection processes, observations and interpretations, or actively, through formal searches, trend analyses and forecasting to predict threats and opportunities (Daft \& Weick, 1984).

As a sense and response capability of the firm, technological opportunism is conceptually similar to absorptive capacity, however, the technologically opportunistic firm operates from a very different interpretation of its environment. Technologically opportunistic firms operate under the assumption that their environment is not analyzable and therefore, they actively build new environments through experimentation and trial rather than by following traditional paths or trends (Daft \& Weick 1984). Thus, the technologically opportunistic firm may explore several different technologies in order to assess which technologies pose the greatest potential threats or opportunities (Srinivasan, Lilien, \& Rangaswamy, 2002). Therefore, the technologically opportunistic firm assesses the value of a new technology not by careful evaluation of existing knowledge or experience, but through a process of trial and error to determine what works best.

Another key distinction between technological opportunism and absorptive capacity is the scope of information search behavior. Absorptive capacity enables a firm to acquire, assimilate and act upon new knowledge from its knowledge environment, the macroenvironment in which a firm operates (Van Den Bosch, Volberda, \& De Boert, 1999). Technological opportunism, however, has a narrow focus of seeking and responding to opportunities or threats that it perceives specifically within the firm's technological environment (Shoham, et al. 2017).

Based on the review of the extant literature and given the general lack of research into how a firm's perceptions of a technological innovation are formed or how a firm's dynamic capabilities might inform those perceptions, the central aim of this article is to provide answers to the proposed research questions in order to explain why firm-level technological innovation adoptions succeed or fail.

http://www.open-jim.org 


\section{Method}

In this exploratory study, semi-structured depth interviews were conducted with key informants in corporate buying centers to gain insight into how a firm's perceptions of a technological innovation are formed and influenced by internal and external factors (Biemans, Brencic \& Malshe, 2010). The use of key informants, defined as individuals that occupy roles that make them knowledgeable of the phenomena being researched (Campbell, 1955), is consistent with prior innovation and technology adoption research (Rindfleisch \& Moorman, 2001; Ganesan, Malter, \& Rindfleisch, 2005). Semi-structured interviews allow the interviewer to probe for deeper responses, thus providing greater detail and insight into a given response.

Key informants were identified through the business outreach office of a large research university in the southern U.S. as well as through personal business connections. Participants were prequalified as individuals holding senior management positions within their firms and as having been materially involved in a recent firm decision to adopt a technological innovation as a member of their organization's buying center. A purposeful effort was made to recruit respondents from a broad range of industries. Six participants were identified and five additional participants were recruited through direct referrals from among the initial six contacts. Among the respondents, three worked in the area of higher education, three in the area of financial services, two in the area of healthcare, two from the area of manufacturing and one from a utility cooperative. Participants ranged in age from 40 to 57 with an average age of 47.36 years. Nine of the eleven participants were male, and the average interview length was 47 and a half minutes long. Each participant was informed that their responses would remain confidential, that they could choose to decline to answer any question and were free to stop the interview at any time. Each respondent was given a pseudonym and their business is identified only by broad industry category. Table 1 provides an overview of key informant characteristics.

Table 1. Key Informant Characteristics

\begin{tabular}{|c|c|c|c|c|}
\hline Pseudonym & YOB & Job Title & Industry & Interview Length \\
\hline 1. Jim & 1966 & Deputy $\mathrm{ClO}$ & Higher Education & $34: 39$ \\
\hline 2. Gina & 1973 & Assistant Director & Higher Education & $31: 33$ \\
\hline 3. Rhonda & 1971 & Vice President & Financial Services & $35: 20$ \\
\hline 4. James & 1963 & Logistics Officer & Healthcare & $68: 55$ \\
\hline 5. Adam & 1974 & Retail Product Manager & Financial Services & $30: 42$ \\
\hline 6. Jeffrey & 1961 & Logistics Officer & Healthcare & $44: 18$ \\
\hline 7. Jackson & 1972 & Sr. Web Developer & Higher Education & $51: 32$ \\
\hline 8. Don & 1965 & Marketing Director & Utility Cooperative & 38:06 \\
\hline 9. Kent & 1971 & Product Manager & Financial Services & $54: 58$ \\
\hline 10. Nick* & 1960 & Engineering Director & Manufacturing & $85: 14$ \\
\hline Ted* & 1957 & General Manager & Manufacturing & - \\
\hline \multicolumn{5}{|c|}{ *Participants interviewed together } \\
\hline
\end{tabular}

Interviews were conducted either by telephone or in person. Interviews were recorded electronically and transcribed verbatim using a third-party transcription service. After briefing participants on the purpose of the interview, respondent demographic data was collected. Because respondents 
may interpret terminology differently, respondents were given definitions and examples of how the terms "technology", "adoption decisions", and "transformational technology" are defined in this study. After confirming respondents were clear on the desired interpretation of terms, they were asked to provide an overview of their company, including its core products and services, key competitive strengths, years in business, and number of employees. Respondents were then asked to define their specific role within the firm and their role within the corporate buying center as related to technology adoption decisions. An interview guide was developed for the semi-structured interviews (see Appendix).

Because a firm's knowledge management capabilities influence its decision-making ability (Slater \& Narver, 1995; Zhou, Yim, \& Tse, 2005; Vargo \& Lusch, 2004; Cohen \& Levinthal, 1990; Jansen, Van Den Bosch, \& Voberda, 2005), respondents were asked specific questions about their firms' knowledge management processes. Likewise, respondents were asked specifically about the role technology plays in their respective firm's daily operations. To understand the processes involved in firm-level technology adoption decisions, respondents were asked to think of a specific instance when their firm adopted a new, technological innovation in which they were directly involved in the decision as a member of the firm's buying center. Further, they were asked to describe their firm's evaluation procedures and the outcomes of the adoption decision. After answering additional follow-up questions, participants provided an assessment of the pros and cons of their firm's processes for technology adoption decisions. This question allowed for greater insight into the aspects of the technology adoption process that led to adoption decisions that were perceived to be successful and which aspects resulted in adoption decisions that did not meet the firm's expectations. Participants were given a final opportunity to add additional information or insight to the discussion - either in specific terms related to a particular adoption decision or from a more gestalt view of the firm's technology adoption process.

Following grounded theory methodology, analysis of the data employed a three-stage, constant comparison procedure including (1) open coding, (2) axial coding, and (3) selective coding (Strauss \& Corbin, 1998). During the open coding process, data were segmented, and key concepts were identified within the data. Each transcript was reviewed individually and coded to identify emergent themes in the data. This provided a broad view of the data. However, open coding can result in numerous codes (Strauss \& Corbin, 1998), therefore it is necessary to further refine and group codes into relevant categories in the axial coding stage. During axial coding, coded transcripts were compared to each other, and similar codes were collapsed into a single code. Themes and codes reached a point of saturation by the sixth interview. Axial coding yielded 37 unique codes with a combined frequency of 2,233 instances across ten interview transcripts.

In the selective coding stage, the 37 unique codes were grouped into three broad categories: Knowledge-Based Capabilities, Adoption Decision Drivers, and Success Measures. The KnowledgeBased Capabilities category includes sub-categories of knowledge type sought, knowledge sources, and knowledge processing. The Adoption Decision Driver category includes sub-categories of innovation characteristics, project characteristics, and firm characteristics. Success Measures does not contain additional subcategories. The frequency of responses by category and illustrative quotes is provided in Table 2. 
Table 2. Emergent Themes, Frequencies and Illustrative Quotes

\begin{tabular}{|c|c|c|c|}
\hline $\begin{array}{l}\text { Response } \\
\text { Category }\end{array}$ & $\mathbf{N}$ & $\begin{array}{l}\% \text { Within } \\
\text { Category }\end{array}$ & Illustrative Quote \\
\hline \multicolumn{4}{|c|}{ Knowledge Seeking } \\
\hline $\begin{array}{l}\text { Technology } \\
\text { Knowledge }\end{array}$ & 160 & 40 & $\begin{array}{l}\text { "Usually what we're looking for is anything that } \\
\text { would replace existing technology that makes us more } \\
\text { efficient, especially in as far as things that reduce the } \\
\text { amount of man hours involved to do a particular task } \\
\text { or deliver a particular service." }\end{array}$ \\
\hline $\begin{array}{l}\text { Market } \\
\text { Knowledge }\end{array}$ & 118 & 29 & $\begin{array}{l}\text { "We always have to continually keep up-to-date to see } \\
\text { what's out there, to see when customers are adopting } \\
\text { particular things... if we don't have that particular } \\
\text { offering then maybe we need to move forward to } \\
\text { adding that." }\end{array}$ \\
\hline $\begin{array}{l}\text { Product/Service } \\
\text { Knowledge }\end{array}$ & 94 & 23 & $\begin{array}{l}\text { "We're a PHP, MYSQL plant shop, so obviously } \\
\text { anything that works with that and is based on that, } \\
\text { that's what we're looking for. We have a lot of } \\
\text { money invested there, so we want to continue to } \\
\text { leverage that." }\end{array}$ \\
\hline $\begin{array}{l}\text { Environment } \\
\text { Knowledge }\end{array}$ & 30 & 7 & $\begin{array}{l}\text { "Number one, in order to find out what we need to be } \\
\text { knowing, because you never know what's going on. } \\
\text { We try to keep abreast of what's going on in the } \\
\text { different industries that we deal with." }\end{array}$ \\
\hline
\end{tabular}

\section{Knowledge Sources}

Direct Vendor 104

Contact

Internal

92
"We have a lot of vendors that reach out to us. If they reach out, we do a face-to-face meeting or we do a webinar or they just send me brochures and I make sure that gets connected with whatever person manages that particular program."

"In that discovery process, we realize that our [commercial banking department] had a remote deposit capture that was scanner-based. So we were able to leverage that existing vendor relationship and that underlying technology to port that into the mobile space." 


\begin{tabular}{|c|c|c|c|}
\hline $\begin{array}{l}\text { Response } \\
\text { Category }\end{array}$ & $\mathbf{N}$ & $\begin{array}{l}\% \text { Within } \\
\text { Category }\end{array}$ & Illustrative Quote \\
\hline Events/Training & 51 & 19 & $\begin{array}{l}\text { "... of the biggest conferences that we send people } \\
\text { to is all about that. There are vendors there and } \\
\text { there's a mini trade show associated with it, but the } \\
\text { biggest focus is not the trade show, it is the } \\
\text { networking, the collaboration..." }\end{array}$ \\
\hline Media & 23 & 9 & $\begin{array}{l}\text { "Linkedln has been something we've been using so } \\
\text { that we can hear what other people in our industries } \\
\text { are doing and then, of course, with now, the } \\
\text { companies are so good about being in the white } \\
\text { papers and they blog and the media uses it to put } \\
\text { out stories and articles." }\end{array}$ \\
\hline
\end{tabular}

\section{Knowledge Processing}

Assimilation $\quad 102$

Transformation

79

31

Exploitation

75

40
"The owners of our bank are very big about collaboration, working together. So, we do a lot of that. We do a lot of committee work versus individual lines of business. While we do have our own responsibilities within our lines of business, we still collaborate via a more committee style process." “.. those doctors are constantly exposed to the latest and greatest in the educational side of medicine. They bring those ideas back. If they've got some great new piece of technology. .. and the doctor is using it over there, he's going to want it [here] too."

29 "As we look at new technology and we make that decision, we don't look at just what it is today, but what could it be...."

\section{Adoption Drivers}

\section{Project Characteristics}

Vendor 80

Relationship

Cost 66
"When we called, we kind of got blown off, they were very disjointed, very segmented. We called our account rep, he was like, I don't know, you need to call these other 22 people to find the right answer for yourself."

"You're looking at a substantial capital expenditure reinvest back in the facility, and not wait until you have this time of failure but just to go ahead and prevent it and move forward." 


\begin{tabular}{|c|c|c|c|}
\hline $\begin{array}{l}\text { Response } \\
\text { Category }\end{array}$ & $\mathbf{N}$ & $\begin{array}{l}\text { \% Within } \\
\text { Category }\end{array}$ & Illustrative Quote \\
\hline Scope/Objectives & 63 & 25 & $\begin{array}{l}\text { "It was a massive undertaking. It cost us } \\
\text { multi-millions of dollars to do that, but we believed } \\
\text { that long term that was the right strategic move for } \\
\text { us to do." }\end{array}$ \\
\hline Perceived Risk & 32 & 13 & $\begin{array}{l}\text { "Lord knows if it goes wrong, we don't want to be the } \\
\text { one to get it wrong because if you get it wrong, } \\
\text { you're known forever for having gotten it wrong." }\end{array}$ \\
\hline $\begin{array}{l}\text { Technology and } \\
\text { Market } \\
\text { Turbulence }\end{array}$ & 15 & 6 & $\begin{array}{l}\text { "Technology is always evolving, product offerings are } \\
\text { always evolving so we need to be on the cutting edge } \\
\text { leading edge of those shifts to make sure that when } \\
\text { we're moving forward in a sufficient manner, not } \\
\text { necessarily maybe being the lead, but that's definitely } \\
\text { being a fast follower." }\end{array}$ \\
\hline \multicolumn{4}{|c|}{ Innovation Characteristics } \\
\hline $\begin{array}{l}\text { Relative } \\
\text { Advantage }\end{array}$ & 92 & 30 & $\begin{array}{l}\text { "They have a manufacturing base over here. It's a } \\
\text { newer design. The motor and gearbox are generally } \\
\text { more efficient." }\end{array}$ \\
\hline $\begin{array}{l}\text { Perceived } \\
\text { Compatibility }\end{array}$ & 83 & 27 & $\begin{array}{l}\text { "[The new technology] played well with [our current } \\
\text { system] and we knew that was going to be key." }\end{array}$ \\
\hline $\begin{array}{l}\text { Perceived } \\
\text { Complexity }\end{array}$ & 64 & 21 & $\begin{array}{l}\text { "We weren't going to a fully custom system - we did } \\
\text { buy it off the shelf and were able to brand it and just } \\
\text { use it basically out of the box because it was a } \\
\text { proven technology." }\end{array}$ \\
\hline Observability & 33 & 11 & $\begin{array}{l}\text { "...we were able to see how it worked and we were } \\
\text { able to kind of benchmark our product against what } \\
\text { other banks were doing. }\end{array}$ \\
\hline Trialability & 31 & 10 & $\begin{array}{l}\text { "... we may trial it for a week... and see how we } \\
\text { like it and then decide if we want to go to it, make } \\
\text { the change if it is cost effective, beneficial, whatever." }\end{array}$ \\
\hline \multicolumn{4}{|c|}{ Firm Characteristics } \\
\hline $\begin{array}{l}\text { Operations - } \\
\text { Formalization }\end{array}$ & 147 & 23 & $\begin{array}{l}\text { "They mandated that each (hospital) network hire a } \\
\text { project manager to manage the implementation at } \\
\text { the network and then to manage it going forward } \\
\text { after the technology was implemented." }\end{array}$ \\
\hline $\begin{array}{l}\text { Market } \\
\text { Orientation }\end{array}$ & 107 & 17 & $\begin{array}{l}\text { "We want to make sure that we're where we need to } \\
\text { be with our system and teaching our faculty what to } \\
\text { do. We have to listen to them. They are our } \\
\text { customers." }\end{array}$ \\
\hline
\end{tabular}




\begin{tabular}{|c|c|c|c|}
\hline $\begin{array}{l}\text { Response } \\
\text { Category }\end{array}$ & $\mathbf{N}$ & $\begin{array}{l}\% \text { Within } \\
\text { Category }\end{array}$ & Illustrative Quote \\
\hline Coalition building & 92 & 14 & $\begin{array}{l}\text { "... if you want it adopted on a widespread basis for } \\
\text { the institution, there's got to be buy-in by the true } \\
\text { leaders of the institution..." }\end{array}$ \\
\hline $\begin{array}{l}\text { Technological } \\
\text { Responsiveness }\end{array}$ & 86 & 13 & $\begin{array}{l}\text { "Technology is always evolving, product offerings are } \\
\text { always evolving so we need to be on the leading edge } \\
\text { of those shifts to make sure that when we're moving } \\
\text { forward in a sufficient manner, not necessarily maybe } \\
\text { being the lead, but that's definitely being a fast } \\
\text { follower." }\end{array}$ \\
\hline Centralization & 84 & 13 & $\begin{array}{l}\text { "Technology is done through what we call our } \\
\text { National Acquisition Center up in Illinois because } \\
\text { anything that is really high dollar and that is } \\
\text { radiology type stuff ... Anything high dollar goes } \\
\text { through them, it has to be bought through them." }\end{array}$ \\
\hline Innovativeness & 68 & 11 & $\begin{array}{l}\text { "But it all builds in the manufacturing line and the } \\
\text { creativity in staying ahead, because everyone else is } \\
\text { going to knock it off. Once they see it out there, oh, } \\
\text { we're going to go make the same product. So you } \\
\text { always keep your product development one step } \\
\text { ahead. It never ends. You're always working. If you } \\
\text { don't, you're going to get rolled up." }\end{array}$ \\
\hline Framing & 58 & 9 & $\begin{array}{l}\text { "... then they make a suggestion to all the other } \\
\text { facilities, you need to look at Brand X because they } \\
\text { are saving a ton of money, it is a really good } \\
\text { product'..." }\end{array}$ \\
\hline
\end{tabular}

\section{Success Measures}

Competitive $\quad 39$

Position
$39 \quad 38$
"They are beating me into submission, even with technology. We've got to find that happy medium between the two of implementing proven technology that we can't afford to have huge missteps because, one, I can't afford it financially, and two, I can't afford it because, if I do it wrong and I'm going to drive my customers out the door."




\begin{tabular}{lccl}
\hline $\begin{array}{l}\text { Response } \\
\text { Category }\end{array}$ & N & $\begin{array}{c}\text { \% Within } \\
\text { Category }\end{array}$ & $\begin{array}{l}\text { Illustrative Quote } \\
\text { Financial }\end{array}$ \\
$\begin{array}{l}\text { Performance } \\
\text { Satisfaction }\end{array}$ & 26 & 25 & $\begin{array}{l}\text { "Inventory data will be much more accurate. There is } \\
\text { a dollar savings there if you do not have errors." } \\
\text { "Well, the level we are at the moment, the level of } \\
\text { control, we're happy. ... from a point of operational } \\
\text { smoothness, it went very well." } \\
\text { "From our perspective, the gear-heads, the technical } \\
\text { people, the only way we can measure it (success) is } \\
\text { how much is it used." }\end{array}$ \\
\hline
\end{tabular}

\section{Findings}

\subsection{Knowledge-Based Capabilities Category}

\section{Knowledge Type Sought}

This subcategory resulted in 402 individual responses being coded. Informants were asked to explain how their firm's existing knowledge and experience influenced the type of new, external knowledge they actively sought and how important they perceived this activity to be to their competitive position. All respondents noted that the acquisition of new knowledge was vital to their operations and identified technology knowledge (40\%), market knowledge (25\%), product/service knowledge (23\%), environmental knowledge $(7 \%)$, and general industry knowledge $(5 \%)$ as primary types of knowledge they sought. Market knowledge included references to customer information, competitor information and information regarding general market or industry trends.

\section{Knowledge Sources}

This subcategory resulted in 270 unique coded responses. Respondents were also asked about the importance of technology to their day-to-day operations and the importance of keeping up-to-date with technology trends. All respondents expressed that keeping abreast of their technological environment as important, with many mentioning the need to remain competitive as well as the importance of being up to date or "relevant." Respondents identified several key sources of new knowledge, with many noting that they found out about new industry trends or technology through direct contact with sales representatives, peer organizations and industry professionals (39\%), via cross-departmental knowledge sharing, and existing knowledge and experience (34\%), from external events, including industry trade shows, seminars, and training sessions (19\%), and from the media (9\%).

\section{Knowledge Processing}

This subcategory resulted in 256 coded responses. Respondents further discussed their internal processes for assimilating and integrating new knowledge into the firm's existing knowledge structures, as well as for leveraging new knowledge to enhance firm performance. These included informal processes to formal knowledge management procedures utilized to codify and integrate new knowledge. Responses included processes indicating knowledge assimilation (40\%), knowledge transformation (31\%) and knowledge exploitation (29\%). 


\subsection{Adoption Decision Drivers Category}

\section{Innovation Characteristics}

This subcategory resulted in 303 coded responses. Consistent with extant literature regarding innovation characteristics as drivers of adoption decisions, respondents identified relative advantage $(30 \%)$, perceived compatibility $(27 \%)$, and perceived complexity $(21 . \%)$ as the primary aspects that influenced the technological innovation adoption decision. In addition to these attributes, respondents also identified the observability of the innovation $(11 \%)$ and the opportunity for trial use of the technology $(10 \%)$ as important factors influencing their adoption decision.

\section{Project Characteristics}

In addition to aspects of the innovation itself, respondents noted several aspects related to the innovation and the environmental conditions as drivers of the adoption decision. This subcategory generated 256 individually coded responses. Consistent with relationship marketing literature (Morgan \& Hunt, 1994; Tuli, Kohli, \& Bharadwaj, 2007; Palmatier, 2008), respondents noted the importance of the firm's existing relationship with the innovation supplier (31\%) as influential to their adoption decision. In addition, the financial impact of the adoption decision on the firm was also influential, with project cost $(26 \%)$, project scope and objectives $(25 \%)$, and perceived risk $(13 \%)$ among the key responses. Finally, turbulence in both the technology environment (5\%) and the market in general $(1 \%)$ were also identified as adoption decision drivers.

\section{Firm Characteristics}

Consistent with extant literature, respondents noted a number of firm characteristics that influenced their technology adoption decisions. The Firm Characteristics subcategory generated 644 individually coded responses. Among firm characteristics related to policies and procedures (operations) were most prominent $(23 \%)$, followed by market orientation $(17 \%)$. Responsiveness to technological changes $(13.35 \%)$, firm innovativeness $(11 \%)$, and firm size $(<1 \%)$ were also identified as important firm characteristics that drive the adoption decision. Micropolitical strategies including coalition building (14\%) and framing (9\%) were identified in addition to centralization of decision making $(13 \%)$ and CEO support $(<1 \%)$ as important influencers of the technology adoption decision.

\section{Success Factors Category}

Respondents were specifically asked during the interviews how they measured the success of their respective technology adoption decisions. This category resulted in 102 coded responses. Interviewees identified enhancement of the firm's competitive position (38\%) and measures of financial performance $(25 \%)$ as the primary success measure of an adoption decision. In addition, respondents identified satisfaction with the technology (20\%), and among service businesses, client use of the new technology $(17 \%)$ as indicators of the success of the technology adoption decision.Success Factors Category. Respondents were specifically asked during the interviews how they measured the success of their respective technology adoption decisions. This category resulted in 102 coded responses. Interviewees identified enhancement of the firm's competitive position (38\%) and measures of financial performance $(25 \%)$ as the primary success measure of an adoption decision. In addition, respondents identified satisfaction with the technology (20\%), and among service businesses, client use of the new technology $(17 \%)$ as indicators of the success of the technology adoption decision. 


\subsection{Model Conceptualization}

Consistent with the extant literature, the findings of the qualitative study indicate numerous internal and external factors that influence firm-level technology adoption decisions. Expectancydisconfirmation theory suggests that satisfaction with an adoption decision is at least in part influenced by the firm's expectations for the performance of the adopted technology (Oliver, 1980). In the innovation adoption literature, expectations for a technology's performance are embodied in the firm's perceptions of the technology's relative advantage, perceived compatibility and perceived complexity (Rogers, 1962). However, in a B2B buying situation, a cognitive gap often exists between an innovation "supplier's interpretation of the buyer's expectation and the buyer's actual expectations" (Ashok, Day, \& Narula, 2018, 132). Thus, a firm's evaluation of a technology's relative advantage, compatibility and complexity may be either overly optimistic, leading to negative disconfirmation of performance and dissatisfaction with the adoption decision, or more realistic or even slightly pessimistic, leading to positive disconfirmation of performance and satisfaction with the adoption decision. Overly pessimistic evaluations would likely result in the decision to not adopt the technology. Therefore, in response to the call from Abrahamson (1991), it is reasonable to assume that it is a firm's flawed perceptions of an innovation that drive some firms to adopt inferior innovations and other firms to reject superior innovations. In either case, the evaluations of a technology's relative advantage, perceived compatibility and perceived complexity are in some way inaccurate, thus rendering them unreliable in predicting satisfaction with an adoption decision. Therefore, to aid both adopting and supplier firms in their ability to effectively predict satisfaction with the adoption decision, it is necessary to identify the internal and external factors that influence the accuracy of the firm's expectations for the technology's performance.

\section{Dynamic Capabilities}

Dynamic capabilities enable the firm to acquire, modify and deploy resources, including knowledgebased resources utilized to inform innovation and strategic decision-making. These capabilities include sensing capabilities (recognizing opportunities and threats), response capabilities (exploiting opportunities and minimizing threats) and reconfiguring capabilities (modifying operational capabilities and resources) (Gebauer, 2011).

Consistent with extant literature (e.g Srinivasan, Lilien, \& Rangaswamy, 2002; Lin et al., 2016; Shoham et al., 2017), analysis of the interview data revealed that a firm's technology sense and response capabilities play an important role in driving the firm's technology adoption decision. For example:

- "We must always be looking at the new technologies. Again, if we sit here like we are today3 years from now we won't be around. We'll be gone." (Kent, Financial Services)

- "There's just the usual stuff where you just see something and think, "Man, that's kind of an interesting thing. Can we adopt that here in what we do?" (Don, Electric Cooperative)

- "If you're going to implement new technology, then it's going to have to interface with legacy systems, and then when you try to do it and it doesn't interface with them or it doesn't interface very well or unreliably, well we just wasted a bunch of money." (James, Healthcare)

Therefore, we suggest the following research proposition:

- P1: A firm's technology sense and response dynamic capability will have a positive relationship with the accuracy of the firm's perceptions of the relative advantage, compatibility and complexity of a new technology.

http://www.open-jim.org 
Furthermore, specific knowledge-based capabilities that emerged from the textual data included aspects of potential and realized absorptive capacity, as illustrated in these quotes:

- "I present that [technology] to a strategic steering committee to ensure that we have the resources to move forward. There's also risk, our ERM committee, and we present any technology that we want to do to them so they can look at it from a risk, compliance and legal point of view." (Adam, Financial Services)

- "[The firm] looks at all their facilities to see if there is something a facility picked up that can be incorporated into a [firm] wide project or program, and then they elevate that to central office to see if it could be market wide." (Jeffrey, Healthcare)

- "The value proposition is much better for members now because we can control our costs using technology and at the end of the day not have to raise rates, making their interaction with us easier and cheaper." (Don, Electric Cooperative)

Potential absorptive capacity is the firm's ability to identify, acquire and assimilate new knowledge and realized absorptive capacity describes the firm's ability to transform and exploit new knowledge (Jansen, Van Den Bosch, and Volberda, 2005). It is proposed that these dynamic capabilities play a direct role in shaping the firm's understanding and evaluation of specific attributes of a new technology, including perceptions of its relative advantage, compatibility and complexity. Thus, the following proposition is made:

- P2: A firm's absorptive capacity dynamic capability will have a positive relationship with the accuracy of the firm's perceptions of the relative advantage, compatibility and complexity of a new technology.

\section{Moderating Variables}

Sharma, Durand and Gur-Arie (1981) define moderating variables as variables that influence the strength or the form of the relationship between a predictor and criterion variable. The qualitative study identified several additional variables, both internal and external to the firm, that have influence over the technology adoption decision. However, this discussion will explore those variables that are likely to have the greatest influence on the firm's perceptions of a new technology. For example, the qualitative findings indicate that observability of the technology and the opportunity for trial use of the technology prior to adoption can influence the adoption decision.

- "We made multiple site visits to other banks that were running this software. We traveled to three other banks, talked to couple other banks, and we actually attended their user conferences prior to us making the decision." (Kent, Financial Services)

- "There was a pilot. We've never been an innovator in any of these. [If the firm] is going to make a decision, they're going to take a long time to do it, they're going to take a long time to deploy it." (Gina, Higher Education)

Both observability and trialability are identified by Rogers (1962) as drivers of the technology adoption decision, in addition to relative advantage, perceived compatibility, and perceived complexity. Because observability and trialability are direct observations of a technology and not based solely on perceptions, they will likely moderate the relationship between the firm's absorptive capacity and technology sensing capabilities and the firm's perceptions of the technology.; therefore, we make the following propositions:

- P3: The observability of a technology will moderate the observed relationship between a firm's (a) technology sense and response dynamic capabilities, its (b) absorptive capacity dynamic 
capabilities, and its perceptions of the relative advantage, compatibility and complexity of a new technology.

- P4: The trialability of a technology will moderate the observed relationship between a firm's (a) technology sense and response dynamic capabilities, its (b) absorptive capacity dynamic capabilities, and its perceptions of the relative advantage, compatibility and complexity of a new technology.

The qualitative study also identified perceived risk among the variables influential to the adoption decision. For example:

- "So, what we're faced with at the moment is one of those suppliers has basically gone through a number of changes. But they basically now only manufacture this particular range of gearboxes, which is certainly not cost-effective and the lead times are just ridiculous." (Nick, Manufacturing)

- "We'd done all of our due diligence on everything. We'd gotten our vendor. We'd had our interviews. We all felt really great about it. We were ready to go, and they had a call with the vendor and they said, "I just can't get comfortable with this. So, it's a no-go." (Rhonda, Financial Services)

These quotes illustrate perceptions of various risks the firm is exposed to in making the decision to adopt new technology. There is evidence in the extant literature to support the notion that such perceptions of risk will have a moderating effect on a firm's understanding of a technology and its decision to adopt it. For example, Chen and Huang (2017) find that the relationship between an e-tail product provider's perception of how well a technology will perform the tasks for which it is intended and its intention to purchase the technology is significantly moderated by the firm's perception of performance risks associated with the decision. Likewise, Obal and Morgan (2018) find perceptions of technological change negatively moderates the influence of goal orientation on acceptance of new technology. Thus, we suggest the following research proposition:

- P5: A firm's perception of risk associated with the adoption of a technology will moderate the observed relationship between a firm's (a) technology sense and response dynamic capabilities, its (b) absorptive capacity dynamic capabilities, and its perceptions of the relative advantage, compatibility and complexity of a new technology.

The findings of the qualitative study also revealed a number of variables related to the internal micro-political environment of the firm. These included activities related to coalition building, including CEO support, and framing of the adopted technology as a strategic advantage for the firm. For example:

- "It meant buying-in at the highest level to encourage faculty to use it, the formation of the [teaching resource department] to help support faculty in using [the technology] and so forth and so on. That's the thing that adoption of a technology, you got to have the support." (Jim, Higher Education)

- "They will crunch the numbers and do the math, then they make a suggestion to all the other facilities, "Hey, you need to look at Brand $X$ because they are saving a ton of money, it is a really good product, it is green certified." (Jeffrey, Healthcare)

- "Our CEO and the owner of the bank did spend a significant amount of time sharing, visiting with different groups, different departments, the different branches, the different areas, and making sure they understand why we were doing this strategically. Our entire executive team helped to champion this on our behalf." (Kent, Financial Services) 
March (1962) argues that the firm is a collection of political coalitions of internal and external stakeholders that place resource demands on the firm, resulting in conflicts. Evangelists are the core of the coalition and are often powerful or charismatic individuals within the firm, e.g. the CEO, who can overcome resistance to the innovation (Rogers, 1995; Yadav, Pabhu, \& Chandy, 2007; Su \& Baird, 2018). These evangelists recognize the potential of the proposed technology, adopt the project as their own and are personally committed to promoting the technology. Evangelists and their respective coalitions often employ the micro-political strategy of framing to gain the necessary support from important stakeholders (Hillman \& Hitt, 1999). This micro-political activity is therefore expected to moderate the relationship between a firm's knowledge-based dynamic capabilities and its perceptions of a new technology. Therefore, the following propositions are made:

- P6: Coalition building associated with the adoption of a technology will moderate the observed relationship between a firm's (a) technology sense and response dynamic capabilities, its (b) absorptive capacity dynamic capabilities, and its perceptions of the relative advantage, compatibility and complexity of a new technology.

- P7: Framing activity associated with the adoption of a technology will moderate the observed relationship between a firm's (a) technology sense and response dynamic capabilities, its (b) absorptive capacity dynamic capabilities, and its perceptions of the relative advantage, compatibility and complexity of a new technology.

\section{Other Variables}

The qualitative study also identified other variables that have also been explored in the literature as drivers of firm-level technology adoption. Factors including market orientation (Slater \& Narver 1995), firm innovativeness (Deshpandé, Farley \& Webster, 1993), firm size and centralization of decision making (Damanpour, 1991) are shown in the literature to be factors indicative of the firm's capability and/or willingness to pursue new technological innovations but not necessarily factors that would influence the firm's perceptions of those innovations. Similarly, observed factors in the qualitative study including technology turbulence (e.g. Autry et al., 2010) and vendor relationship strength (e.g. Gázquez-Abad, Canniére, \& Martínez-López, 2011) have been shown in the literature to moderate the relationship between a firm's perceptions of technology and its decision to adopt the technology. Therefore, these variables were not included in the conceptual model, which examines just those factors that influence a firm's perception of a technological innovation.

Through the development of these research propositions based on the review of the literature and the findings of the qualitative study, a conceptual model of firm-level technology adoption processes is presented (see Figure 1).

\section{Discussion}

The research questions presented are addressed by the review of the literature and analysis of the qualitative study, which culminates in the conceptual model presented in Figure 1. First, this study finds that a firm's dynamic capabilities play a central role in informing the firm's perceptions of a technological innovation's characteristics that drive the adoption decision. From an expectancydisconfirmation perspective, it is a firm's knowledge-based dynamic capabilities that inform the firm's expectations for the performance of a technological innovation. This supports current research in this area (e.g. Lin, Su, \& Higgins, 2016) and addresses the call from Abrahamson (1991) for greater understanding into why firms sometimes adopt inferior innovations and reject 


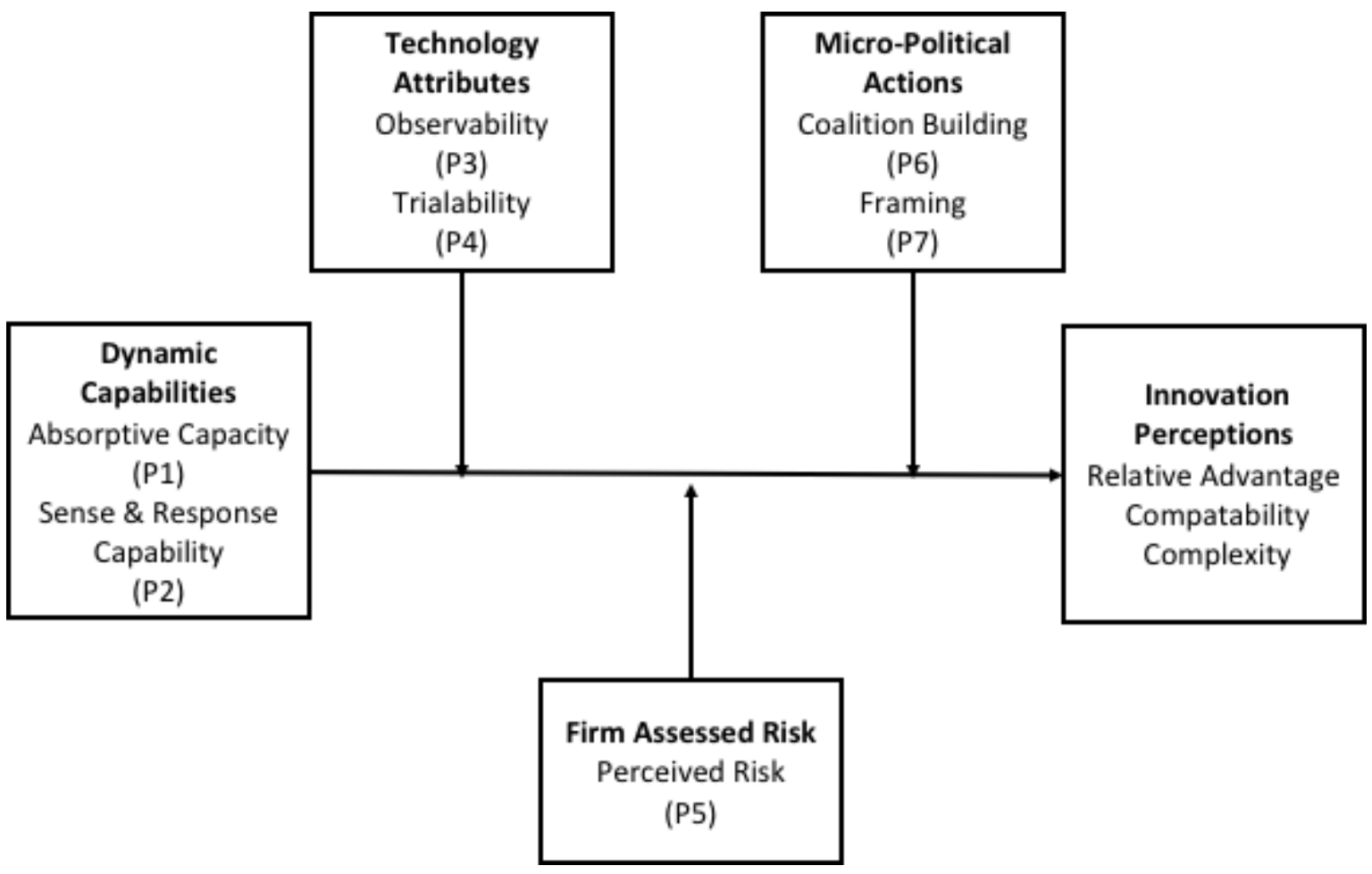

Figure 1. Firm-Level Technology Adoption Framework

superior ones. Second, the study identifies several factors that influence the relationship between a firm's dynamic capabilities and the perceptions they inform. Specifically, this study identifies the firm's perception of risk associated with the adoption decisions, internal firm micro-politics, and information provided by the opportunity to observe or trial use of the technological innovation. It is expected that when a firm has relatively poor knowledge-based dynamic capabilities, these other factors will have much greater influence over how the firm perceives the innovation. Conversely, as a firm increases in its knowledge-based dynamic capabilities, expectations for the performance of a technological innovation will be less impacted by these moderating factors.

The findings make several contributions to both theory and practice. First, these findings add important context to diffusion of innovation theory. While much research has explored the diffusion of innovations, relatively few studies have explored the question as to why so many innovation adoption decisions end in failure. By examining the problem through the lens of expectancy-disconfirmation theory, we find that when the expectations for the performance of a technological innovation are unrealistic, then it is likely the firm will be dissatisfied with the adoption decision. Thus, the key to driving successful innovation adoption decisions is to begin with successfully managing and informing the expectations of the adopting firm. Second, this study contributes to expectancy-disconfirmation theory by identifying knowledge-based capabilities as an antecedent condition for the formation of a firm's expectations for performance that drives adoption intent and satisfaction.

This study also has several managerial implications, both for firms supplying and firms adopting technological innovations. Consistent with the findings of Bunduchi et al. (2015) and Obal (2017), adopting firm managers should first ensure that goals related to the adoption of the technology are clearly defined, including the technology's ability to deliver the expected value-added benefit to customers, the roles and responsibilities of internal stakeholders and alignment of the adoption decision with overall organizational goals and objectives. Second, managers must control the 
influence of micro-politics on their technology adoption decisions. Virtually all the interviewees in the qualitative study expressed the importance of gaining buy-in and support from key stakeholders to ensure the successful adoption of a new technology. Narayanan and Fahey (1982) contend that "the politics of decision-making must be managed... the process of the generation and utilization of strategic information must be managed" ( $p$ 32). Therefore, managers should utilize multiple channels of information to avoid perceptions of biased information from a single source. In addition, managers should be careful to manage relationships between individuals, project teams, departments, etc. that consider themselves to be stakeholders in the technology adoption decision. Consistent with recommendations from Tuli, Kohli, and Bharadwaj (2007), this study's findings suggest that to ensure a successful implementation, adopting firms must effectively counsel their supplier firm on the firm's operational and political landscape as well as ensure a breadth of relationships are formed with relevant stakeholders in both firms (Palmatier, 2008).

This study also has important implications for marketers of technological innovations. It is important for supplier firms to effectively manage their customer's expectations for the performance of the technological innovation (Ashok, Day, \& Narula, 2018). Through the collection of market intelligence and relationship marketing activities, supplier firms should first assess the knowledgebased dynamic capability of the buying firm and identify key personnel within the firm's buying center. By focusing on building multiple relationships throughout the adopting firm to increase relationship quality and efficacy, supplier firms can ensure consistent communication of the technological innovation's value throughout the buying center to better manage performance expectations (Tuli, et al., 2007).

While this study offers insights for both marketing theory and practice, its limitations as an exploratory study should be noted. While care was taken to interview senior managers from a variety of industries, their technology adoption experiences may be unique to their individual firms and thus not generalizable. Further, this study sought to only explore the adoption of technological innovations and does not address other types of innovations firms may adopt; thus, any implications should not be generalized for all innovations. Future research should seek to test the proposed framework and propositions presented here to provide empirical evidence of the relationships and further inform our understanding of dynamic capabilities, the role of potential moderating factors, and their impact on shaping a firm's expectations for the performance of an adopted technology.

\section{References}

Abrahamson, E. (1991). Managerial fads and fashions: The diffusion and rejection of innovations, Academy of Management Review, 16(3), 586-612.

Adams, F. G. \& Graham, K. W. (2017). Integration, knowledge creation and B2B governance: The role of resource hierarchies in financial performance, Industrial Marketing Management, 63, 179-91.

Ashok, M., Day, M., \& Narula, R. (2018). Buyer (dis)satisfaction and process innovation: The case of information technology services provision, Industrial Marketing Management, 68, 132-144.

Autry, C. W., Grawe, S. J., Daugherty, P. J., \& Richey, R. G. (2010). The effects of technological turbulence and breadth on supply chain technology acceptance and adoption, Journal of Operations Management, 28(6), 522-36.

Biemans, W. G., Brencic, M. M., \& Malshe, A. (2010). Marketing-Sales Interface Configurations 
in B2B Firms, Industrial Marketing Management, 39(2), 183-94.

Bunduchi, R., Smart, A., Charles, K., McKee, L. \& Azurara-Blanco, A. (2015). When Innovation Fails: An Institutional Perspective of the (Non)adoption of Boundary Spanning IT Innovation, Information \& Management, 52(5), 563-76.

Campbell, D.T. (1955). The Informant in Quantitative, Research, American Journal of Sociology, 60(4), 339-42.

Chen, C. \& Lien, N. (2013). Technological Opportunism and Firm Performance: Moderating Contexts, Journal of Business Research, 66(11), 2218-25.

Chen, Y. \& Huang, S. (2017). The effect of task-technology fit on purchase intention: The moderating role of perceived risks, Journal of Risk Research, 20(11), 1418-38.

Choi, K., Jean, R., \& Kim, D. (2019). The impacts of organizational learning capacities on relationship-specific innovations: Evidence from the global buyer-supplier relationship, International Marketing Review, 36(6), 1042-1066.

Christensen, C. M. (2011). The Innovator's Dilemma, New York: Harper Business.

Cohen, W. M. \& Levinthal, D. A. (1990). Absorptive Capacity: A New Perspective on Learning and Innovation, Administrative Science Quarterly, 35(1), 128-52.

Daft, R. L. and Weick, K.E. (1984). Toward a Model of Organizations as Interpretation Systems, Academy of Management Review, 9(2), 294-95.

Damanpour, F. (1991). Organizational Innovation: A Meta-Analysis of Effects of Determinants and Moderators, Academy of Management Journal, 34(3), 555-90.

Davis, F. D. (1989). Perceived Usefulness, Perceived Ease of Use, and User Acceptance of Information Technology, MIS Quarterly, 13(3), 319-40

Del Carmen, Arias-Aranda, H., D., Lloréns-Montes, F. J., \& Moreno, A. R. (2007). The Impact of Absorptive Capacity on Technological Acquisitions Engineering Consulting Companies, Technovation, 27(8), 417-25.

Del Carpio Gallegos, J. \& Torner, F. (2018). Absorptive capacity and innovation in low-tech companies in emerging economies, Journal of Technology Management \& Innovation, 13(2), 3-10.

Deshpandé, R., Farley, J. U., \& Webster Jr., F. E. (1993). Corporate culture, customer orientation, and innovativeness in Japanese firms: a quadrad analysis, Journal of Marketing, 57(1), 23-37.

Durmusoglu, S. S., Hirunyawipada, T., \& McNally, R. C. (2017). New product development process implementation in a business-to-business firm: The driving and moderating factors for improved program performance and time-to-market, Journal of Business-to-Business Marketing, 24(1), 35-56.

Eisenhardt, Kathleen M. \& Jeffrey A. Martin (2000). Dynamic Capabilities: What Are They? Strategic Management Journal, 21(10/11), 1105-1121.

Fitzgerald, D. (2013, Dec. 11). Avon Scraps $\$ 125$ Million Troubled Software Overhaul, Wall Street Journal, 262(139), Accessed April 15, 2015,

http://www.wsj.com/articles/SB10001424052702303932504579251941619018078.

Flatten, T. C., Engelen, A., Zahra, S. A., \& Brettel, M. (2011). A Measure of Absorptive Capacity: Scale Development and Validation, European Management Journal, 29(2), 98-116. 
Frambach, R. T. \& Schillewaert, N. (2002). Organizational innovation adoption: A multi-level framework of determinants and opportunities for future research, Journal of Business Research, 55(2), 163-76.

Ganesan, S., Malter, A. J., \& Rindfleisch, A. (2005). Does Distance Still Matter? Geographic Proximity and New Product Development, Journal of Marketing, 69(4), 44-60.

Gázquez-Abad, J. C., De Canniére, M. H., \& Martínez-López, F. J. (2011). Dynamics of customer response to promotional and relational direct mailings from an apparel retailer: The moderating role of relationship strength, Journal of Retailing, 87(2), 166-81.

Gebauer, H. (2011). Exploring the contribution of management innovation to the evolution of dynamic capabilities, Industrial Marketing Management, 40(8), 1238-50.

Gray, B. \& Ariss, S. S. (1985). Politics and Strategic Change Across Organizational Life Cycles, Academy of Management Review, 10(4), 707-23.

Heide, J. B., \& Weiss, A. M. (1995). Vendor consideration and switching behavior for buyers in high-technology markets, Journal of Marketing, 59(3), 30-43.

Henschen, D. (Dec.16, 2013). Inside Avon's Failed Order-Management Project, Information Week, Accessed April 25, 2015, http://www.informationweek.com/software/informationmanagement/inside-avons-failed-order-management-project/d/d-id/1113100.

Hillman, A. J. \& Hitt, M. A. (1999). Corporate Political Strategy Formulation: A Model of Approach, Participation, and Strategy Decisions, Academy of Management Review, 24(4), 825-42.

Hughes, B. (Sept. 22, 2017). 3 Trends Driving Modern Manufacturing Innovation, Retrieved from https://www.entrepreneur.com/article/300596

Hurley, R. F. \& Hult, T. M. (1998). Innovation, Market Orientation, and Organizational Learning: An Integration and Empirical Examination, Journal of Marketing, 62(3), 42-54.

Jansen, J. J.P., Van Den Bosch, F. A. J., \& Volberda, H. W. (2005). Managing Potential and Realized Absorptive Capacity: How do Organizational Antecedents Matter? Academy of Management Journal, 48(6), 999-1015.

Jelinek, R., Ahearne, M., Mathieu, J., \& Schillewaert, N. (2006). A Longitudinal Examination of Individual, Organizational, and Contextual Factors on Seals Technology Adoption and Job Performance, Journal of Marketing Theory and Practice, 14(1), 7-23.

Kanaracus, C. (November 5, 2010). ERP Woes Blames for Lumber Company's Bad Quarter, Computerworld, Accessed April 15, 2015, http://www.computerworld.com/article/2513991/enterpriseapplications/erp-woes-blamed-for-lumber-company-s-bad-quarter.html.

Kapoor, K. K., Dwivedi, Y. K., \& Williams, M. D. (2014). Rogers' Innovation Adoption Attributes: A Systematic Review and Synthesis of Existing Research, Information Systems Management, 31(1), 74-91.

Krigsman, M. (2010, November 11). Understanding Lumber Liquidators' ERP failure, Retrieved March 10, 2015, from https://www.zdnet.com/article/understanding-lumber-liquidatorserp-failure/.

Lechner, C. \& Floyd, S. W. (2012). Group Influence Activities and the Performance of Strategic Initiatives, Strategic Management Journal, 33(5), 478-95.

Lin, H.-F., Su, J.-Q., \& Higgins, A. (2016). How dynamic capabilities affect adoption of 
management innovations, Journal of Business Research, 69(2), 862-76.

Lucia-Palacios, L., Bordonaba-Juste, V., Polo-Redondo, Y., \& Grünhagen, M. (2014). Technological Opportunism Effects on IT Adoption, Intra-firm Diffusion and Performance: Evidence From the U.S. and Spain, Journal of Business Research, 67(6), 1178-88.

Mai Anh, N., Hui, L., \& Khoa, V. D. (2018). Emerging Economies of Southeast Asia: Achieving and increasing radical innovations through collaborating with buyers and suppliers by fostering trust: the case of Viet Nam, Journal of Business-to-Business Marketing, 2(4), 357-372.

March, J. G. (1962). The Business Firm as a Political Coalition, The Journal of Politics, 24(4), 662-78.

Mishra, A. N. \& Agarwal, R. (2010). Technological Frames, Organizational Capabilities, and IT Use: An Empirical Investigation of Electronic Procurement, Information System's Research, 21(2), 249-70.

Moorman, C. (1995). Organizational Market Information Processes: Cultural Antecedents and New Product Outcomes, Journal of Marketing Research, 32(3), 318-35.

Morgan, R. M., \& Hunt, S. D. (1994). The commitment-trust theory of relationship marketing. Journal of Marketing, 58(3), 20-38.

Mustak, M. (2019). Customer participation in knowledge intensive business services: Perceived value outcomes from a dyadic perspective, Industrial Marketing Management, 78, 76-87.

Narayanan, V. K. \& Fahey, L. (1982). The Micro-Politics of Strategy Formulation, Academy of Management Review, 7(1), 25-34.

Nooteboom, B. (1989). Diffusion, uncertainty and firm size', International Journal of Research in Marketing, 6(2), 109-28.

O'Neal, C. R., Thorelli, H. B., \& Utterback, J. M. (1973). Adoption of Innovation by Industrial Organizations, Industrial Marketing Management 2(3), 235-50.

Obal, M. (2017). What drives post-adoption usage? Investigating the negative and positive antecedents of disruptive technology continuous adoption intentions, Industrial Marketing Management, 63, 42-52.

Obal, M. \& Morgan, T. (2018). Investigating the moderating effects of perceived technological change on sales force acceptance, Journal of Business-to-Business Marketing, 25(4), 319-338.

Oliver, R. L. (1980). A Cognitive Model of the Antecedents and Consequences of Satisfaction Decision, Journal of Marketing Research, 17(4), 460-9.

Palmatier, R. W. (2008). Relationship marketing. Cambridge: Marketing Science Institute.

Park, C. \& Lee, H. (2015). Value co-creation processes - early stages of value chains involving high-tech business markets: Samsun-Qualcomm Semiconductor Foundry Businesses, Journal of Business-to-Business Marketing, 22(3), 229-252.

Parker, C. P., Dipboye, R. L., \& Jackson, S. L. (1995). Perceptions of Organizational Politics: An Investigation of Antecedents and Consequences, Journal of Management, 21(5), 891-912.

Rindfleisch, A. \& Moorman, C. (2001). The Acquisition and Utilization of Information in New Product Alliances: A Strength-of-Ties Perspective, Journal of Marketing, 65(2), 1-18.

Rogers, E. M. (1962). Diffusion of Innovations. New York: The Free Press. 
Rogers, E. M. (1995). Diffusion of Innovations, 4th Edition. New York: The Free Press.

Rubera, G. \& Kirca, A. H. (2012). Firm Innovativeness and Its Performance Outcomes: A Meta-Analytic Review and Theoretical Integration, Journal of Marketing, 76(3), 130-47.

Sarkees, M. (2011). Understanding the Links Between Technological Opportunism, Marketing Emphasis and Firm Performance: Implications for B2B, Industrial Marketing Management, 40(5), 785-95.

Sethi, R., Iqbal, Z., \& Sethi, A. (2012). Developing New-to-the-Firm Products: The Role of Micropolitical Strategies, Journal of Marketing, 76(2), 99-115.

Sharma, S., R. Durand, M., \& Gur-Arie, O. (1981). Identification and analysis of moderator variables, Journal of Marketing Research, 18(3), 291-300.

Shoham, A., Asseraf, Y., Lev, S., \& Fiegenbaum, A. (2017). Marketing and technological absorptive capacities: Environmental antecedents and performance outcomes in high-tech firms, Journal of Business-to-Business Marketing, 24(3), 165-182.

Slater, S. F. \& Narver, J. C. (1995). Market Orientation and the Learning Organization, Journal of Marketing, 59(3), 63-74.

Slater, S. F., J. J. Mohr, \& S. Sengupta. (2014). Radical Product Innovation Capability: Literature Review, Synthesis, and Illustrative Research Propositions, Journal of Product Innovation Management, 31(3), 552-66.

Srinivasan, R., Lillien, G. L., \& Rangaswamy, A. (2002). Technological Opportunism and Radical Technology Adoption: An Application to E-Business, Journal of Marketing, 66(3), 47-60.

Staples, D. S., Wong, I., \& Seddon, P. B. (2002). Having expectations of information systems benefits that match received benefits: does it really matter? Information \& Management Journal, 40(2), 115-31.

Strauss, A., \& Corbin, J. (1998). Basics of qualitative research techniques. Thousand Oaks: Sage Publications.

Su, S. \& Baird, K. (2018). The role of leaders in generating management innovation, International Journal of Human Resource Management, 29(19), 2758-2779.

Teece, D. J., Pisano, G. \& Shuen, A. (1997). Dynamic Capabilities and Strategic Management, Strategic Management Journal, 18(7), 509-533.

Tordova, G. \& Durisin, B. (2007). Absorptive Capacity: Valuing a Reconceptualization, Academy of Management Review, 32(3), 774-86.

Tuli, K. R., Kohli, A. K., \& Bharadwaj, S. G. (2007). Rethinking Customer Solutions: From Product Bundles to Relational Processes, Journal of Marketing, 71(3), 1-17.

Van Den Bosch, F. A. J., Volberda, H. W., \& De Boer, M. (1999). Coevolution of Firm Absorptive Capacity and Knowledge Environment: Organizational Forms and Combinative Capabilities, Organization Science, 10(5), 551-68.

Vargo S. L., \& Lusch, R. F. (2004). Evolving to a New Dominant Logic for Marketing, Journal of Marketing, 68(1), 1-17.

Witt, L. A., Andrews, M. C., \& Kacmar, K. M. (2000). The Role of Participation in DecisionMaking in the Organizational Politics-Job Satisfaction Relationship, Human Relations, 53(3), 341-58. 
Wonglimpiyarat, J. (2010). Innovation index and the innovative capacity of nations, Futures, 42(3), 247-53.

Yadav, M. S., Prabhu, J. C., \& Chandy, R.K. (2007). Managing the Future: CEO Attention and Innovation Outcomes, Journal of Marketing, 71(4), 84-101.

Yaghoubi, M., Teymourzadeh, E., Bahadori, M., \& Ghardashi, F. (2017). Conceptual Model of Innovation Capability in Industrial and academic Research Centers: A Systematic Review, Iranian Journal of Management Studies, 10(3), 609-40.

Zahra, S. A. (1987). Organizational Politics and the Strategic Process, Journal of Business Ethics, 6(7), 579-87.

Zahra, S. A. \& George, G. (2002). Absorptive Capacity: A Review, Reconceptualization, and Extension, The Academy of Management Review, 27(2), 185-203.

Zaltman, G., Duncan, R., \& Holbeck, J. (1973). Innovations and Organizations. New York: Wiley, .

Zhou, K. Z., Yim, C. K., \& Tse, D. K. (2005). The Effects of Strategic Orientations on Technologyand Market-Based Breakthrough Innovations, Journal of Marketing, 69(2), 42-60.

Zobel, A. (2017). Benefiting from Open Innovation: A Multidimensional Model of Absorptive Capacity, Journal of Product Innovation Management, 34(3), 269-288. 


\section{Appendix}

\section{Semi-structured Interview Guide}

\section{Company and Individual Role Questions}

1. Give me a brief overview of your company.

(a) What role does your department play within the firm?

(b) What is your specific role within your department?

\section{Knowledge Management Questions}

2. Thinking about your competitive environment, how does your firm's existing market knowledge and experience influence the type and amount of new external knowledge you seek?

(a) What types of things does your firm seek new information about?

(b) Once you acquire new information, how is it disseminated throughout the firm?

(c) After acquiring new knowledge, what processes are in place to act upon it?

\section{Technology Focus Questions}

3. Thinking specifically about the technological environment in your industry, in what ways does technology impact your day-to-day operations?

(a) How does your firm find out about new technologies that may affect your business?

(b) How is that information shared with others in the company?

(c) Describe how your firm leverages technology to achieve its goals.

\section{Adoption Decision Questions}

For these next questions, think about a specific time your firm successfully or unsuccessfully adopted new transformational technology.

4. Describe the circumstances that prompted the decision to adopt the new technology.

(a) What was it about the technology that ultimately influenced the adoption decision?

\section{Buying Center Questions}

5. Tell me about the different people/departments that were involved in the adoption decision process.

(a) How was the technology "pitched" to this group?

(b) Describe the dynamics of the group and any efforts that were undertaken to rally support or to voice opposition for the technology.

\section{Success Measures Questions}

6. How do you measure success of the adoption decision?

(a) What do you think went right/wrong with the decision?

(b) If you could go back and change anything in the way the technology adoption decision was made, what would you change? 


\section{Biographies}

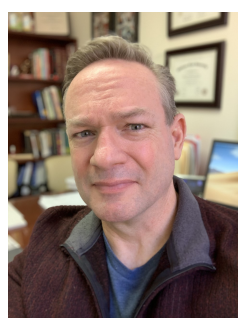

Kenneth W. Graham. Dr. Kenneth Graham is an Assistant Marketing Professor at the University of Wisconsin-La Crosse's College of Business Administration, specializing in mediamediated consumer-brand relationships, B2B relationship marketing, and brand strategy. His research has appeared in Industrial Marketing Management, Journal of Research in Interactive Marketing, and Marketing Education Review. In addition, Dr. Graham has presented his research at several national conferences, including the Academy of Marketing Science and the Society for Marketing Advances.

CRediT Statement: Conceptualisation, Investigation, Formal Analysis, Methodology, Writing Original Draft, Review and Editing, Visualization.

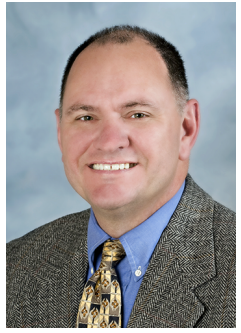

Robert S. Moore. Dr. Robert Moore is the Hunter Henry Fellow and Professor of Marketing at Mississippi State University. He has published multiple articles in peer reviewed scholarly journals, including Journal of the Academy of Marketing Science, Journal of Business Research, Journal of Advertising, Journal of Services Marketing, Journal of Interactive Marketing, Journal of Social Psychology, and Journal of Public Policy \& Marketing. Dr. Moore has won numerous awards for his teaching and research.

CRediT Statement: Supervision, Conceptualisation, Reviewing and Editing. 